\title{
Comprehensive description of the matter of land lease
}

\author{
Maria Matveeva ${ }^{1}$ and Olga Kholodova ${ }^{1, *}$ \\ ${ }^{1}$ Irkutsk National Research Technical University, 664074, Lermontova str., 83, Irkutsk, Russia
}

\begin{abstract}
The solution of land issues is one of the most important factors in the development and implementation of investment and construction projects. In this particular aspect, land lease issues are the least researched ones. Lease is considered as a tool to increase the efficiency of the use of federal lands in order to improve investment activity in the development of new territories. In this paper, the main aspects of the concept of lease are presented in a complex form. Also, basic algorithms for evaluating the market value of land are considered. One type of management mechanisms is specifically outlined - a rental mechanism of land resources in state (federal and municipal) ownership, intended for the purposes of implementing innovative projects.
\end{abstract}

The Irkutsk region covers an area of 767.9 thousand $\mathrm{km}^{2}$ (4.6\% of the territory of Russia). Therefore, it occupies the sixth place in Russia [1 State report "On the state and protection of the environment in the Irkutsk region in 2016". - Irkutsk: Megaprint Ltd., 2017. 274 pp.].

As follows from the report [1], as of 01.01.2017, most of the territory of the Irkutsk region is occupied by the lands of the forest fund $-89.48 \%(69,331.6$ thousand hectares) of the total area of the region's land fund. The remaining six categories account for only $10.52 \%$, of which: the share of the category of agricultural land is only $3.72 \%(2,883.9$ thousand hectares), the land of settlements is $0.51 \%$ (398.6 thousand hectares), $0.75 \%$ of the land is occupied by industrial and other special purpose lands ( 577.3 thousand hectares), $0.64 \%$ are the reserve lands (499.5 thousand hectares), the share of lands of specially protected territories and objects is $2.00 \%$ (1,552.4 thousand hectares), and the land of the water fund is $2.89 \%(2,241.5$ thousand hectares). Table 1 presents data on the distribution of the land fund of the Irkutsk region by land categories [1].

The solution of land issues is one of the most important factors for the development and implementation of investment and construction projects. In this aspect, the issue of land lease is the least studied one. Lease is considered as a tool to increase the efficiency of the use of federal lands in order to improve investment activity in the development of new territories. The proposed clarification allows a principal possibility of the invariability of the current management system provided that the parameters and boundaries of the competence of the relevant subjects of management can be adjusted. The main aspects of the concept of lease are presented in a complex form (Figure 2).

*Corresponding author: hololan@mail.ru 
As for the content and form of lease relations, full accounting of all conditions of the lease transaction is a mandatory requirement for their practical implementation. Only in this case the efficient result can be achieved, that is, the equal profitability of the rent. In this connection, it can be argued that in the management aspect, it is advisable to adopt a factor rent model, as the content of the system characteristic of the lease.

Table 1. Distribution of the land fund of the Irkutsk region by land categories.

\begin{tabular}{|c|c|c|c|c|}
\hline No & Name of the land category & $\begin{array}{l}\text { For the } 1 \text { st } \\
\text { of January 2016, } \\
\text { thousand ha }\end{array}$ & $\begin{array}{l}\text { For the } 1 \text { st } \\
\text { of January } 2017 \\
\text { thousand ha }\end{array}$ & $\begin{array}{c}\text { Difference, } \\
\text {, thousand } \\
\text { ha }\end{array}$ \\
\hline 1. & Augricultuural land, including & 2885,1 & 2885,1 & $-1,2$ \\
\hline 1.1 & Land redistribution fund & 202,5 & 202,1 & $-0,4$ \\
\hline 2. & Settlement land & 400,5 & 398,6 & $-1,9$ \\
\hline 3. & Industrial land & 573,2 & 577,3 & $+4,1$ \\
\hline 4. & $\begin{array}{l}\text { Land of specially protected natural } \\
\text { sites }\end{array}$ & 1552,4 & 1552,4 & 0 \\
\hline 5. & Forest reserve land & 69332,4 & 69331,6 & $-0,8$ \\
\hline 6. & Water reserve land & 2241,5 & 2241,5 & 0 \\
\hline 7. & Reserve land & 499,5 & 499,3 & $-0,2$ \\
\hline \multicolumn{2}{|c|}{ Total within administrative boundaries } & 77484,6 & 77484,6 & 0 \\
\hline
\end{tabular}

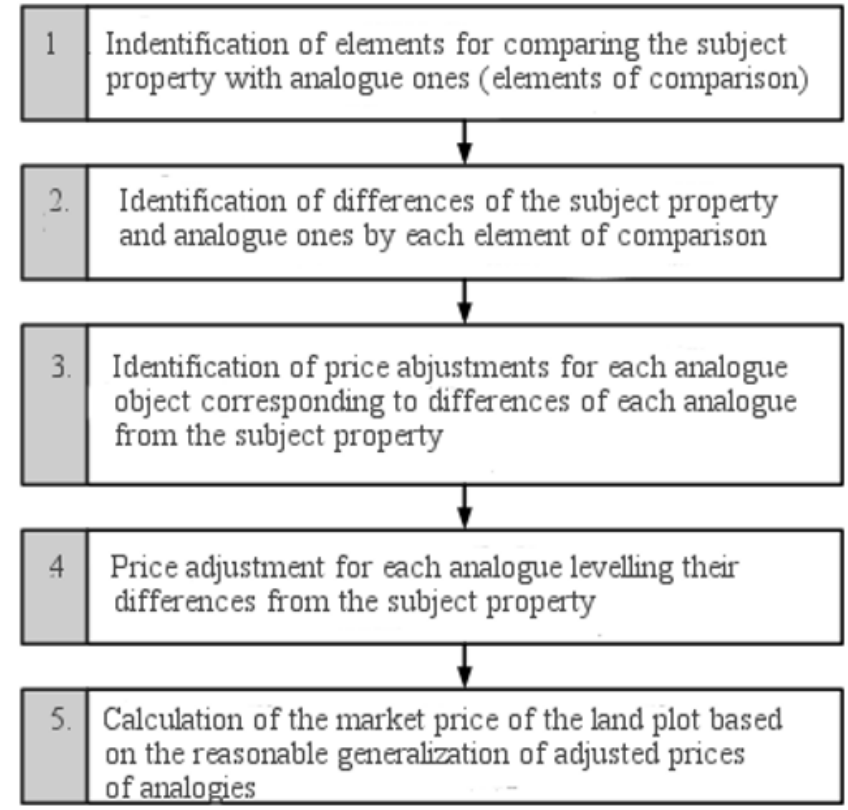

Fig. 2. Basic algorithms for evaluating the market value of land. 


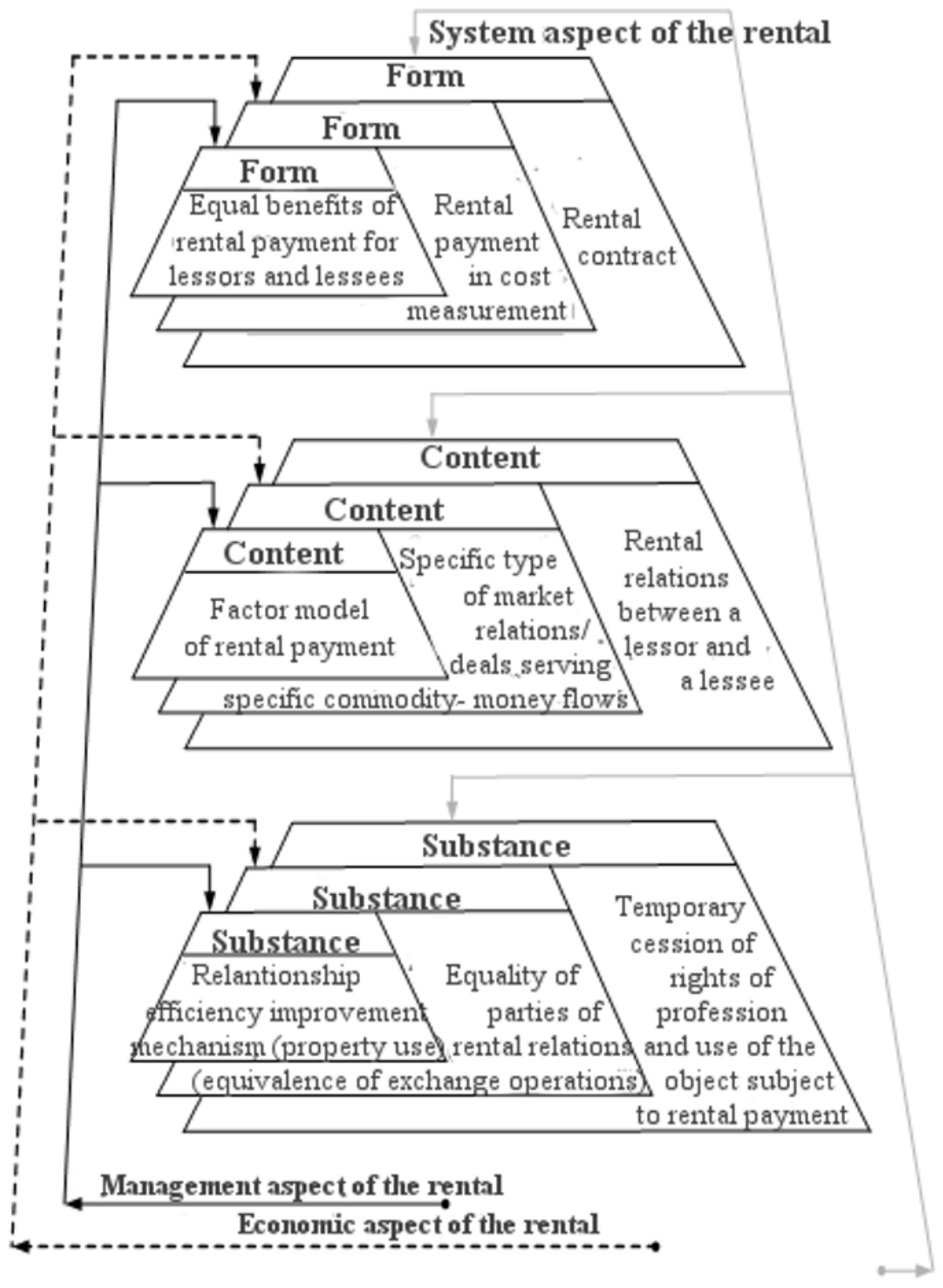

Fig. 2. Comprehensive description of the essence of the lease.

It is based on the evaluation of the market value of land. The basic evaluation algorithms are given below (Figure 1).

The content of the management impacts is to identify the composition, the relative importance and the nature of the relationship of these factors.

The main cost factors and characteristics of transactions with land plots are shown on the Figure 3. 


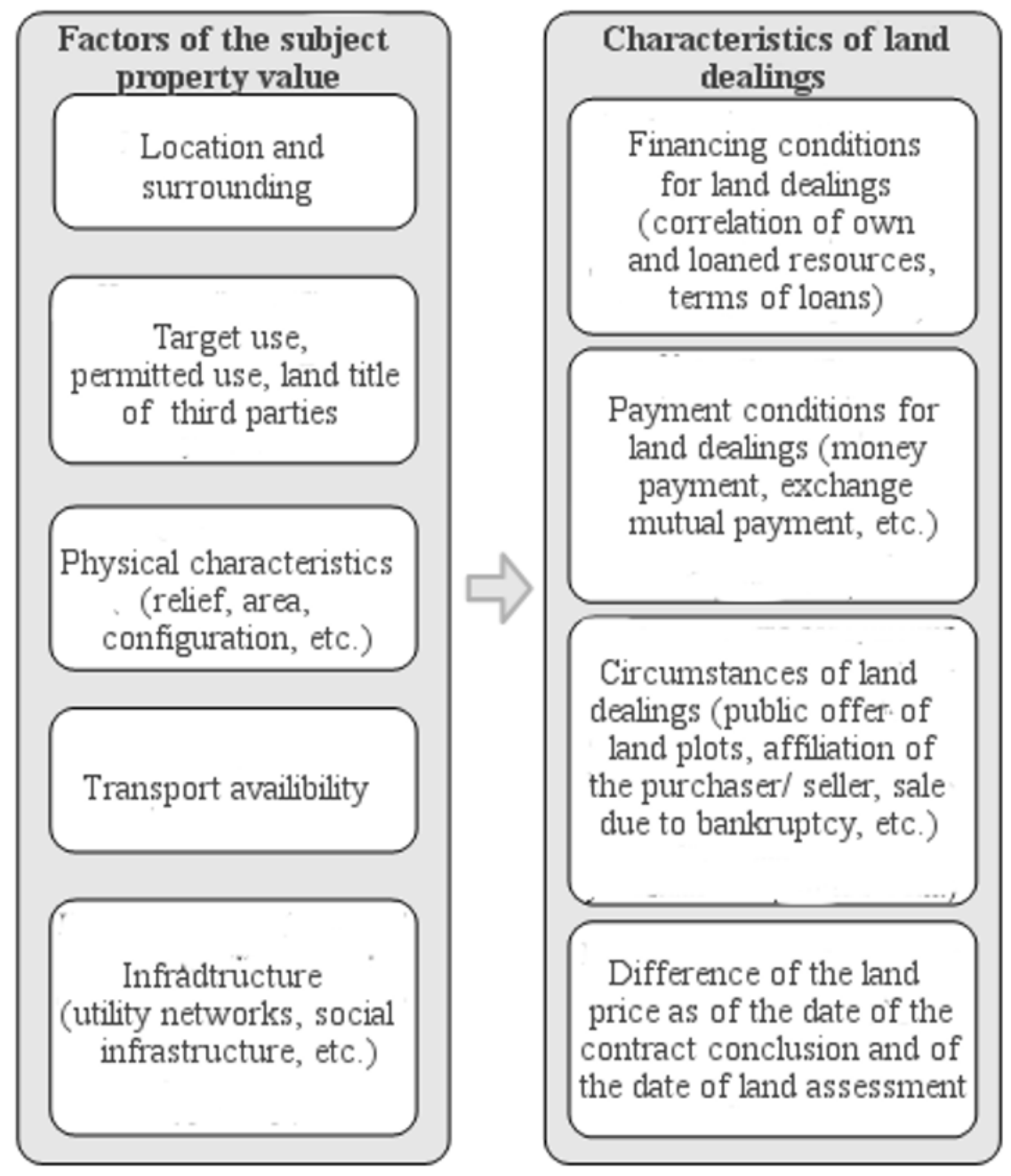

Fig. 3. Main cost factors and characteristics of transactions with land plots.

At the same time, in order to identify the importance of rent in the implementation of mechanisms for managing state property, object detailing is necessary.

It is carried out with the purpose of revealing specific features of realization of a particular kind of economic relations with reference not to the general set of objects of property, but to their certain kind, that is, to the land resources which are in the state ownership. As a result of object detailing, particular forms of lease relationships should be identified, specific only for the land resources involved in the construction process.

The final characteristic takes the following form (Figure 4). 


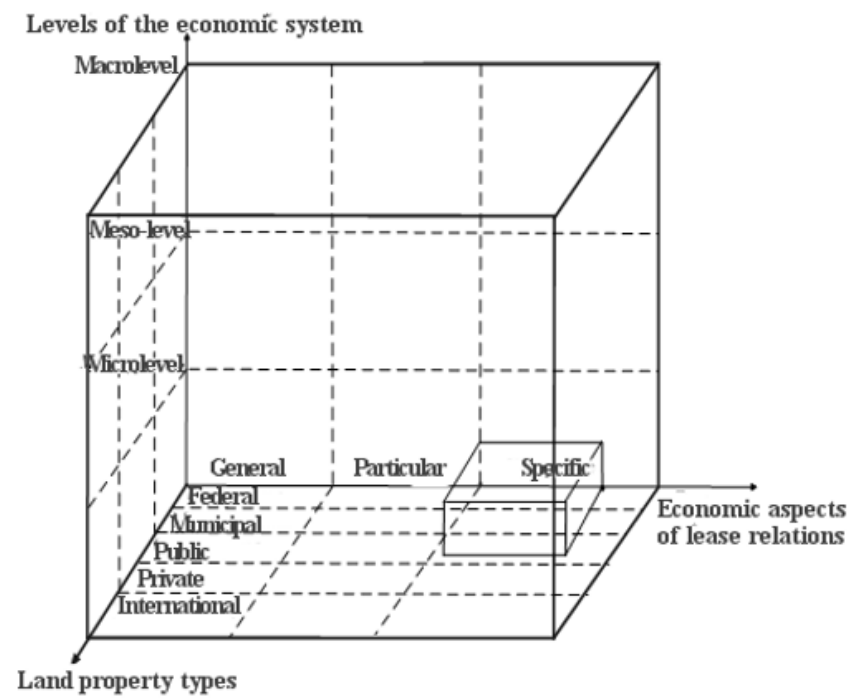

Fig. 4. Decomposition of lease relations (economic aspect).

Based on the obtained structure, the administrative decomposition is carried out. On the Figure 5, a modification of the lease, in accordance with the previously justified logic of the analysis, is presented. It interprets possible hierarchical levels. In accordance with the fundamentals of the Russian state structure, the levels of the hierarchy of the economic system are adequate to the hierarchical levels of the system of power and administration. As for the object characteristics, they remain practically unchanged.

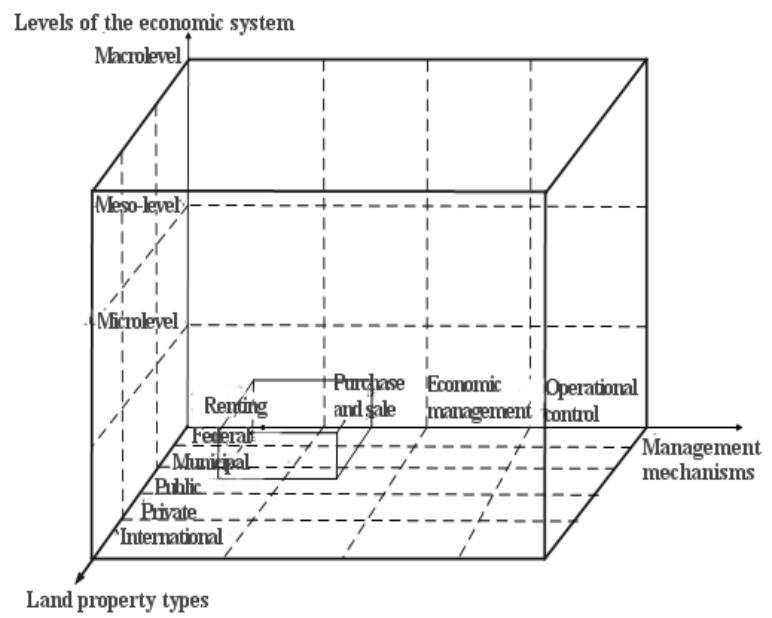

Fig. 5. Rent decomposition (management aspect).

In the decomposition scheme (management aspect), the subject vector is to be transformed. As previously defined by a specific type of economic relations, the essence of management, as applied to the land resource, is the application of management mechanisms implemented in the hierarchy of the management system at various levels. Based on the above, the options for the practical use of real estate will manifest themselves in the content 
of the subject vector. The main options are rent, purchase and sale, and operational management, as well as economic management.

Thus, one type of the management mechanisms that is the rental mechanism of the land resources in the state (federal and municipal) ownership intended for the purposes of implementing innovative projects is to be specifically outlined.

\section{References}

1. V. V. Avekov, Rent in the system of state and municipal property management (Moscow, 1999)

2. R. Alain, Economic indices (Statistics, Moscow, 1980)

3. $\mathrm{V}$. Yu. Anuprienko, Management of state property in the system of regional economy (Economics, Moscow, 2007)

4. A. N. Asaul, P. Yu. Erofeev, Real estate economics (Peter, 2008)

5. Yu. O. Bakrunov, Development: organizational and legal regulation (RAGS, Moscow, 2006)

6. Yu. O. Bakrunov, Proceedings of the Irkutsk State Technical University, 4(32), 44-48 (2007)

7. Yu. O. Bakrunov, Entrepreneurship (2007)

8. Yu. O. Bakrunov, Materials of the Report of the All-Russian Scientific Research Institute of Problems of Scientific and Technical Progress and Information in Construction (2007)

9. M. V. Barkhatov, E. A. Galinovskaya, Yu. G. Zharikov, Comments on the land legislation of the Russian Federation (Yurayt, Moscow, 2003)

10. B. E. Bolshakov, O. L. Kuznetsov, Sustainable development: the scientific basis of design in the system of nature - society - man (Humanistics, Moscow, 2002)

11. I. A. Bush, Protection of the rights of participants in lease relations under Russian law (Saratov, 2011)

12. M. Kh. Vakhaev, The theory and practice of regulation of land relations in market conditions (Publishing House "Juridical Center Press," St. Petersburg, 2006)

13. P. G. Grabovy, R. G. Kvachadze, Proceedings of the Congress "10 Years of Appraisal Activity in Russia" (2003)

14. V. V. Peshkov, L. A. Osherin, Bulletin of Economic Integration, 6, 129-134 (2010)

15. O. A. Kholodova, M. V. Matveeva, Architecture and construction: new technologies in design, construction, economics and management, 176-185 (2016)

16. D. V. Dayneko, A. I. Dayneko, V. V. Peshkov, N. Ya. Kalyuzhnova, Proceedings of high schools. Investments. Building. Real Estate, 3(22), 116-120 (2017)

17. V. V. Peshkov, P. I. Kasyanchik, Economical Annals-XXI, 1(1-2), $50-53$ (2014) 